\title{
TREČIOJO AMŽIAUS UNIVERSITETO VEIKLA NACIONALINĖS MOKSLO PROGRAMOS „SVEIKAS SENĖJIMAS” KONTEKSTE: KLAIPE்DOS RAJONO ATVEJIS
}

\author{
Laura Sèleniené \\ Klaipédos valstybine kolegija \\ DOI: https://doi.org/10.52320/svv.vOiVI.202
}

\begin{abstract}
Anotacija
Straipsnyje aktualizuojamos senstančios visuomenès diktuojami iššūkiai. Vienas jų - sveikos ir kokybiškos senatvès užtikrinimas. Jo svarbą liudija rekomendacijų, programų, gairių ir stategijų, nukreiptų i vyresnio amžiaus asmenų gyvenimo kokybę, gausa. Nacionalinè mokslo programa „Sveikas senèjimas“ - vienas iš dokumentų, apibrěžiančių senstančios visuomenès problemas. Jos turinyje akcentuojamas mokslo indèlis senstančios visuomenès problemoms spręsti. Svarbūs šiame kontekste ne tik mokslo sprendimai, o ir jų skaida tikslinei auditorijai - vyresnio amžiaus asmenims. Tai diktuoja tarpinstitucinès sąveikos svarbą. Straipsnyje išskiriama auštojo mokslo ir vyresnio amžiaus asmenis telkiančių organizaciju sąveika, kaip viena iš sveiko senėjimo idèjos realizavimo prielaidų. Ji suponuoja poreikị ịvertinti mokslo sprendimų integraciją i i vyresnio amžiaus asmenų švietimą ir jị vykdančių organizacijų potencialą sveiko senèjimo kontekste.
\end{abstract}

Pagrindiniai žodžiai: sveikas senėjimas, Trečiojo mžiaus universitetas, vyresnio amžiaus asmenys.

\section{Ivadas}

Temos aktualumas. Mažejjantys gimstamumo rodikliai ir ilgejjanti gyvenimo trukmė lemia visuomenès senèjimo tendencijas. Per ateinančius dešimtmečius vyresnio amžiaus žmonių dalis, palyginti su visu gyventojų skaičiumi, gerokai didès. Europos Sajungos statistikos tarnybos (Eurostat) prognozėmis, iki 2060-ųjų dvigubai padidès $65 \mathrm{~m}$. ir vyresnių žmonių skaičius darbingo amžiaus žmonių atžvilgiu. Šią amžiaus kategoriją (65 ir vyresni) pastaroji organizacija, taip pat Pasaulio sveikatos organizacija (PSO) apibrèžia kaip pagyvenusius asmenis. Lietuvoje ši amžiaus riba daugmaž sutampa su pensiniu amžiumi (moterų - 63,4 metų, vyrų - 64,2 metų).

Gyventojų senėjimo tendencijos ir auganti dirbančiųjų bei pensinio amžiaus asmenų skaičiaus disproporcija tampa iššūkiu įvairioms viešojo ir privataus sektoriaus sritims, ypač sveikatos priežiūros ir socialinių paslaugų sistemai. Tai liudija tarptautiniu bei šalies mastu kuriamos ir reglamentuojamos rekomendacijos, gairès, strategijos sveikam ir kokybiškam senėjimui užtikrinti: Europos 2012-2020 metų sveiko senėjimo strategija ir veiksmų planas; Politikos gairès „Sveikata 21 - sveikata visiems 21ame amžiuje; Nacionalinė mokslo programa „Sveikas senëjimas“ ir kt.

Šaltiniuose išryškèja tampri sveiko senejjimo ir visuomenès švietimo sąsaja. Šios sritys išskiriamos kaip prioritetinès dedamosios ir vertinant gyvenimo kokybę atskirose valstybėse. Tokia nuostata - svari prielaida sveiką senėjimą analizuoti lygiagrečiai su visuomenès švietimu, orientuotu i vyresnių žmonių kategoriją, atkreipiant dėmesi i sveiko senėjimo nuostatas igyvendinančias institucijas. Pasaulyje jos ịvardijamos ịvairiai: senjorų universitetais, senjorų kolegijomis, trečiojo amžiaus universitetais (TAU) ir kt. Pastarasis pavadinimas naudojamas apibūdinant ir Lietuvoje veikiančias mokymo įstaigas vyresnio amžiaus asmenims. LR Švietimo ịstatyme nèra konkretizuotas ar apibrèžtas vyresnių žmonių švietimas. Apsiribojama neformalaus švietimo sąvoka, teigiančia, kad tai švietimas pagal ịvairias švietimo poreikių tenkinimo, kvalifikacijos tobulinimo, papildomos kompetencijos igijimo programas, išskyrus formaliojo švietimo programas. „Tai mokymasis, lavinimasis ar studijos atliepiančios asmens ir visuomenès interesus, o baigus mokslus neišduodamas valstybès pripažįstamas dokumentas, patvirtinantis išsilavinimo, tam tikros jo pakopos ar atskiro reglamentuoto modulio baigimą arba kvalifikacijos igijimą“, - papildoma LR neformaliojo suaugusiųų švietimo ir tęstinio mokymosi įstatyme.

Tyrimo problema: Kaip rodo statistika, vyresnio amžiaus asmenų ịsitraukimas ị TAU veiklas sparčiai auga. $2018 \mathrm{~m}$. atliktos TAU Lietuvoje situacijos analizès duomenimis, pirmasis TAU šalyje atsirado $1995 \mathrm{~m}$., $2012 \mathrm{~m}$. veikè 24 TAU, $2014 \mathrm{~m}$. buvo žinoma net 40 tokią veiklą ịvairiuose šalies miestuose vykdančių institucijų, o $2018 \mathrm{~m}$. - net 65. Sparti jų plètra ir aktyvus lankytojų įsitraukimas svari prielaida peržiūrèti TAU veiklas ir ịvertintini, kaip jos atliepia vyresnio amžiaus asmenų 
poreikius ir valstybès veiklos kryptis šioje srityje. Nuostatos igyvendinant sveiko senèjimo idèją Lietuvoje yra išdèstytos Nacionalinèje mokslo programoje „Sveikas senëjimas“, patvirtintoje $2015 \mathrm{~m}$. vasario 5 d. Lietuvos Respublikos švietimo ministro ịsakymu Nr. V-82. Tai - prielaida TAU veiklas organizuoti ir realizuoti remiantis šia programa, o periodiškas TAU veiklų peržiūrejjimas ir įvertimas svarbus Nacionalinès mokslo programos „Sveikas senejjimas“ igyvendinimo efektyvumo vertinimo aspektas.

Tyrimo objektas - Klaipèdos rajono TAU.

Tyrimo tikslas - ịvertinti Klaipėdos rajono TAU vykdomos veiklos potencialą realizuojant Nacionalinès mokslo programos „Sveikas senejjimas“ nuostatas.

\section{Uždaviniai:}

1. Identifikuoti Klaipedos rajono TAU veiklos apimtis ir formas.

2. Ivertinti, kaip Klaipėdos rajono TAU veiklos atliepia Nacionalinès mokslo programos „Sveikas senejjimas“ gaires.

3. Parengti rekomendacijas Klaipėdos rajono TAU veiklos efektyvinimui.

Tyrimo metodai: mokslinės literatūros apžvalga, dokumentų studijavimas, duomenų analizè.

\section{Sveikas senėjimas ir gyvenimo kokybė}

Remiantis Lietuvos statistikos departamento pateiktais duomenimis (2021), 2020 m. pradžioje 65 m. ir vyresni asmenys sudare apie 20 proc. visos Lietuvos populiacijos (palyginimui $2010 \mathrm{~m}$. - 17,3 proc.). Visuomenès senèjimą liudijantys rodikliai, neabejojama, tik augs, drauge diktuodami veiklos kryptis įvairiose srityse taip pat iššūkius sveikatos ir socialinių paslaugų sektoriui. Vienas iš sprendimo būdų - sveiko senejjimo prioretizavimas.

Demografinių rodiklių pokyčiai lemia dažną sveiko senejjimo sąvokos vartojimą mokslinèje literatūroje. Akcentuotinas visapusiškas tyrējų požiūris ị sveiką senèjimą, nesusitelkiant vien ị fizinę sveikatą. Tai neatsiejama nuo psichologinių, socialinių ar dvasinių veiksnių (Martin ir Gillen, 2014). Dažnai jie akcentuojami kaip sveiko gyvenimo palaikymo elementai, ypač kamuojant ligoms ar užklupus negaliai (Katz ir Calasanti, 2015).

Gustainienès ir Burauskaitės tyrime (2018) šalia sveiko senèjimo sąvokos atsiranda ir sèkmingo senėjimo apibrež̌tis. Autorių pastebėjimu, pastarajam ypač didelę įtaką turi vyresnio amžiaus asmenų sveikatos būklè, o ligos ir negalios ịvardijamos kaip trikdžiai sėkmingam senejjimui.

Merriam ir kt. (2014) pažymi socializacijos svarbą sveikam senejjimui ir tuo pačiu išvardina socializacijai nepalankus faktorius, kurių sąraše dominuoja su sveikata ir fizine savijauta susiję aspektai: negebejjimas prisitaikyti prie naujovių, ịgūdžių stoka, užsienio kalbų barjeras, nelankstumas, energijos ir ištvermès stoka, pasyvumas, ligos. Kaip priešpriešą šiems faktoriams Wister ir kiti (2010) pateikia sveiką senėjimą palaikančias sąlygas: galimybę rinktis ir spręsti pačiam, galimybę būti nepriklausomu nuo kitų, savirealizacijos galimybę ir poreikio mėgautis patenkinimą. Autoriai tai sieja su gyvenimo kokybe.

Sveiką senėjimą kaip kokybiško gyvenimo prielaidą akcentuoja daugelis tyrèjų. Laikantis šios nuostatos akcentuojamas ir sveiką senėjimą lemiantis integralumo aspektas. Pritardama šiai tyrejjų nuostatai, Larkin (2013) išryškina daugiadimensị požiūrị i t sveiką senėjimą, o ji užtikrinančius aspektus ịvardina kaip fizinę sveikatą, psichinę sveikatą, psichologinę gerovę. Toks požiūris ị gyvenimo kokybę atsikartoja ir Bagdono bei kt. monografijoje „Lietuvos gyventojų psichologinė gerovè ir jos veiksniai“ (2013). Čia kokybiškos gyvensenos integralumas iliustruojamas sąvoka „nedaloma viseta“.

Staškutė (2013) sveikatą vyresniame amžiuje taip pat apibrèžia kaip kokybiško gyvenimo dedamają ir akcentuoja su sveikata susijusios gyvenimo kokybės matavimo priemonių taikymo, stebėsenos ir vertinimo svarbą. Autorès pastebėjimu, mokslinèje literatūroje analizuojant gyvenimo kokybės problematiką dominuoja i sveikatą ir jos palaikymą nukreipti tyrimai, kuriuose sveikatos aspektas aptariamas kaip atskira gyvenimo kokybės sritis.

Sveikata kaip svarbi kokybiško gyvenimo dedamoji atsikartoja ir PSO sveiko gyvenimo apibrèžtyje, ị kurią ịtraukiama individo fizinè, psichinè ir socialinè gerovė, o ne tik ligu ir fizinių 
defektų nebuvimas. Išvardinti kokybiškos gyvensenos komponentai būdingi ir Eurostat pateikiam matmenų rinkiniui, kuris naudojamas vertinant gyvenimo kokybę atskirose valstybėse (1 lentelè).

1 lentelè. Gyvenimo kokybės vertinimo matmenų rinkinys

\begin{tabular}{|c|c|}
\hline Materialios gyvenimo sąlygos & Skurdo lygis, gyvenamosios vietos sąlygos, gyvenamo ploto dydis. \\
\hline $\begin{array}{l}\text { Produktyvi ar kita pagrindinė } \\
\text { veikla }\end{array}$ & Bedarbystės lygis, užimtumo kokybè, piliečių aktyvumas. \\
\hline Sveikata & $\begin{array}{l}\text { Gyvenimo trukmè, sveikatos būklè, žalingi ịpročiai, sveikatos priežiūros } \\
\text { prieinamumas. }\end{array}$ \\
\hline Švietimas & Kompetencijos ir įūdžiai, mokymais visą gyvenimą, švietimo galimybės. \\
\hline $\begin{array}{l}\text { Laisvalaikis ir socialinė } \\
\text { sąveika }\end{array}$ & $\begin{array}{l}\text { Santykiai su žmonèmis, savirealizacijos galimybės, socialinè parama, socialinè } \\
\text { sanglauda. }\end{array}$ \\
\hline $\begin{array}{l}\text { Ekonominis saugumas ir } \\
\text { asmens saugumas }\end{array}$ & $\begin{array}{l}\text { Turimas turtas, finansiniai ịsipareigojimai, pajamų stabilumas, nusikalstamumo lygis, } \\
\text { saugumo jausmas. }\end{array}$ \\
\hline $\begin{array}{l}\text { Valdymas ir pagrindinès } \\
\text { teisės }\end{array}$ & Viešojo sektorius paslaugų kokybė, lygios galimybės, aktyvus pilietiškumas. \\
\hline $\begin{array}{l}\text { Gamtinè ir gyvenamoji } \\
\text { aplinka }\end{array}$ & Užterštumas, rekreacinių teritorijų prieinamumas. \\
\hline Bendra gyvenimo patirtis & pasitenkinimas gyvenimu, poveikis bendrai savijautai, tikslai. \\
\hline
\end{tabular}

Eurostat pateikiamas gyvenimo kokybès vertinimo matmenų rinkinys turi tamprių sąsajų su Bagdono ir kt. (2013) monografijoje publikuojamo tyrimo, nukreipto ị skirtingo amžiaus Lietuvos gyventojų pasitenkinimo gyvenimu, rezultatais. Tyrime išskirti aspektai, kurie, tyrèjų manymu, lemia asmenų pasitenkinimą gyvenimu: dabartinis gyvenimas, namų ūkio finansinè padètis, būstas, poilsiui skirta aplinka, gyvenamoji aplinka (infrastruktūra), asmeniniai ryšiai, mėgstamai veiklai skiriamas laikas. 65-erių ir vyresni asmenys šiuos septynis kokybiško gyvenimo apsektus, nulemiančius ir pasitenkinimo gyvenimu pajautą, ịvertino 7,1 balu iš 10 . Šis vertinimas ne daug kuo skiriasi nuo kitų amžiaus kategorijų respondentų.

Kaip matyti mokslinèje literatūroje, sveiko senèjimo apibrèžčių - gausu, taip pat ir modelių, konceptų bei rekomendacijų sveiko senèjimo idèjai realizuoti. Daugeliui jų būdinga holistinis požiūris i sveiką senejjimą, nesikoncentruojant vien ị sveikatą. Tokios nuostatos laikomasi ir Lietuvos mokslo tarybos sudarytoje Nacionalinejje mokslo programoje „Sveikas senejjimas“. Joje akcentuotinos veiklos ir priemonès 2015 - $2021 \mathrm{~m}$. pailginti gyvenimą be ligų ir neigalumo, integruojant inovatyvius diagnostikos ir gydymo metodus, grịstus aukštosiomis technologijomis. Jie pateikiami kaip prielaida, galinti užtikrinti kokybišką bei sveiką senèjimą ir suponuoja Nacionalinės mokslo programos „Sveikas senèjimas" tikslą - kompleksinę Lietuvos visuomenès sveiko senèjimo biomedicinos ir socialinès medicinos klausimų analizę ir sprendimus, pasitelkiant mokslo ir technologijų plètrą, fundamentinių ir taikomųų mokslinių tyrimų rezultatus.

Tikslui pasiekti issipareigojama: „kurti ir tobulinti priemones ir technologijas, skirtas senyvu žmonių galimybėms ir siekiams stiprinti, siekiant geros sveikatos, saugumo, visaverčio dalyvavimo visuomeniniame gyvenime ir savarankiškumo iki gilios senatvès. <...> Naujai kuriamos sveikatos stiprinimo technologijos turès apimti ịvairius metodus ir priemones (ugdymą, teisines, finansines ir organizacines priemones, bendruomenès įtraukimą) ir remtis bendruomenių ịgalinimu“.

Pastaroji nuostata atsikartoja ir LR Sveikatos ministerijos Sveiko senejjimo užtikrinimo Lietuvoje 2014-2023 m. veiksmų plane, išvardinus prioritetines visuomenès sveikatos stiprinimui nukreiptų šveitimo ir edukavimo renginių temas: aktyvumo skatinimas, kraujotakos sistemos ligu profilaktika, onkologinių ligų profilaktika, sveikatos sauga ir stiprinimas, sveika mityba ir nutukimo prevencija.

Sveiko senèjimo prielaidas ir užtikrinimo būdus numatančiuose dokumentuose akcentuojama švietejjiškos veiklos svarba. Tai suponuoja būtinybę Nacionalinės mokslo programos „Sveikas senejjimas" kontekste aktualizuoti vyresnio amžiaus asmenis telkiančias institucijas ir organizacijas, o jų veikloje integruoti programos priemonių nuostatas sveikam senèjimui užtikrinti. Savo veiklų kryptimi, tiksline auditorija ir plètra labiausiai tokią funkciją atliepia vyresnio amžiaus asmenis telkiantys ir, ịprastai, savivaldos iniciatyva ịkurti TAU. 


\section{TAU kaip sveiko senėjimo prielaida}

Nacionalinejje mokslo programoje „Sveikas senejjimas“ išskiriamos dvi asmenų kategorijos: pagyvenusieji - 60 metų amžiaus ir vyresni, senyvi - nuo 75-erių. Lietuvos Respublikos sveikatos ministerija būtent šio amžiaus kategorijos asmenis įvardija kaip tikslinę grupę, kuriai nukreipta sveikos gyvensenos ir kitų profilaktinès sveikatos priežiūros paslaugų plètra. Ṣ̌ amžiaus tarpsnị taip pat akcentuoja Kalvaitis, A. ir kt. (2014), apibrēždami tipinio TAU klausytojo portretą: „moteris, pensininkè, kurios amžius - nuo 60 iki 75 metų“. Paties TAU veiklą apibrèžia Nacionalinè trečiojo amžiaus universitetų asociacija, savo informacinèje platformoje skelbianti, kad vienija: „nevyriausybines organizacijas, besirūpinančias vyresnių nei 50 metų amžiaus žmonių neformaliuoju švietimu ir tęstiniu mokymusi, vyresnio amžiaus žmonių socialine integracija ị visuomenę, tenkina vyresnio amžiaus žmonių žinių, kompetencijų plètotes ir kultūrinius poreikius, palaiko ir skatina šio amžiaus tarpsnio žmonių pilnavertị fizinị ir emocinị gyvenimą, mažina socialinę atskirtị“. Išvardinti TAU siekiai tampriai siejasi su mokslinejje literatūroje išskiriamomis kokybiško gyvenimo prielaidomis ir suponuoja poreikị apibrèžti, kokia TAU funkcijų sąsaja su Stiglitz-Sen-Fitoussi komisijos sudarytu gyvenimo kokybès vertinimo matmenų rinkiniu bei koks TAU veiklos vaidmuo siekiant kokybiškos gyvensenos (2 lentelè).

2 lentelè. Gyvenimo kokybės dedamųjų ir TAU funkcijų sąsaja

\begin{tabular}{|c|c|}
\hline TAU funkcija & Gyvenimo kokybės vertinimo aspektai \\
\hline $\begin{array}{l}\text { - Skatina šio amžiaus tarpsnio žmonių pilnaverti fizinị ir } \\
\text { emocini gyvenimą. } \\
\text { - } \quad \text { Tenkina vyresnio amžiaus žmonių žinių, kompetencijų } \\
\text { plètotes. } \\
\text { - } \quad \text { Mažina socialinę atskirtí. } \\
\text { - } \quad \text { Rūpinasi vyresnio amžiaus žmonių socialine integracija ị } \\
\text { visuomenę }\end{array}$ & $\begin{array}{l}\text { Sveikata. } \\
\text { Produktyvi ar kita pagrindinè veikla. } \\
\text { Švietimas. } \\
\text { Laisvalaikis ir socialinè sąveika. } \\
\text { Bendra gyvenimo patirtis }\end{array}$ \\
\hline
\end{tabular}

Šaltinis: sudaryta autorès.

Sugretinimas rodo, kad TAU funkcijos turi tamprią sąsają net su penkiais iš devynių kokybiško gyvenimo elementų: sveikata, produktyvia ar kita veikla, švietimu, laisvalaikiu ir socialine sąveika bei bendra gyvenimo patirtimi.

Jų užtikrinimo proceso analizės praktikai ir teoretikai nepalieka nuošaly, išgrynindami vyresnio amžiaus asmenų švietimo veiklos charakteristikas. Viena jų - TAU veikloms būtina infrastruktūra. 2014 m. atliktos Trečiojo amžiaus universitetų sistemos veiklos apžvalgos duomenimis, vyresnio amžiaus asmenų švietimui ir edukacijai ịprastai išnaudojamos bibliotekų ir muziejų erdvès, bendrojo lavinimo mokyklos, aukštosios mokyklos, rajonų švietimo ar kultūros centrai, kitos savivaldybèms priklausančios patalpos.

Kitas svarbus aspektas - veiklų planavimas. TAU veiklos iprastai startuoja rudeni, o mokslo metai baigiami pavasarị. Kokios tematikos ir pobūdžio veiklos per mokslo metus bus realizuojamos, iprastai apibrèžiama pasirinkto laikotarpio plane. Tačiau $2012 \mathrm{~m}$. atliktos Trečiojo amžiaus universitetų sistemos veiklos apžvalgos rengejjų pastebejjimu, jis labiau primena renginių tvarkaraščio formatą, nei metodišką ir moksliškai pagrịstą veiklos strategiją. Pastebima, kad ir pačių veiklų pobūdi diktuoja steigejų galimybès, auditorijos pageidavimai, o jų patenkinimas îvardijamas kaip TAU stiprybė. Tai ypatybė, Lietuvos TAU išskirianti iš užsienio valstybėse vyresnio amžiaus asmenis telkiančių organizacijų, labiau savo veiklą koncentruojančių ị akademinę kryptį.

Lietuviškiesiems TAU struktūriškumą ir nuoseklumą suteikia veiklų skirstymas ị fakultetus. Tai - ryškiausias aspektas, priartinantis TAU prie universiteto idejos. I kokius fakultetus skirstyti veiklas, kiekvieno Lietuvoje veikiančio TAU koordinatoriai sprendžia savarankiškai, tačiau pastebima užsièmimų planavimo tendencija, suponuojanti prielaidą TAU veiklas grupuoti i dažniausiai pasikartojančius fakultetus (3 lentelè). 
3 lentelè. TAU fakultetai

\begin{tabular}{|c|c|c|c|}
\hline \multicolumn{2}{|c|}{$\begin{array}{l}\text { Sveikatos, sveikos gyvensenos, sveikatos ir dvasinio } \\
\text { tobulèjimo, sveikatos puoselejjimo, sveikatingumo } \\
\text { gimnastikos. }\end{array}$} & \multicolumn{2}{|c|}{$\begin{array}{l}\text { Socialinès psichologijos, dvasinio tobulèjimo, } \\
\text { humanitarinis, psichologijos, filosofijos. }\end{array}$} \\
\hline $\begin{array}{l}\text { Menŭ, meninès raiškos, šokio teatra } \\
\text { saviraiškos. }\end{array}$ & ras, dramos, & $\begin{array}{l}\text { Politologijos, } \\
\text { socialinès apl }\end{array}$ & $\begin{array}{l}\text { etiškos visuomenės, žmogaus ir } \\
\text { Europos santykių, politinių diskusijų }\end{array}$ \\
\hline $\begin{array}{l}\text { Literatūros, poezijos, skaitytoju } \\
\text { klubas }\end{array}$ & \multicolumn{2}{|c|}{$\begin{array}{l}\text { Informacinių technologijų, } \\
\text { skaitmeninių kompetencijų }\end{array}$} & Muzikos, teatro ir muzikos, dainų \\
\hline Kultūros, kultūros pažinimo & \multicolumn{2}{|l|}{ Teologijos } & Vadybos \\
\hline Turizmo, kraštotyros ir turizmo & \multicolumn{2}{|c|}{ Užsienio kalbų } & Socialinès reabilitacijos \\
\hline Namų ūkio, buities & \multicolumn{2}{|c|}{ Tautodailès, dailès } & Teisès \\
\hline Istorijos, Lietuvos istorijos & \multicolumn{2}{|l|}{ Kartų ryšių } & Rusų filologijos \\
\hline Gerantopsichologijos & \multicolumn{2}{|c|}{ Ichtiologijos } & Drabužių dizaino ir siuvimo \\
\hline
\end{tabular}

Mokslinėje literatūroje akcentuojama, kad socializacija, saviraiškos galimybès, naujų dalyku mokymasis yra kokybiško gyvenimo, o kartu ir sveiko senejjimo prielaidos. Tai iliustruojama 3 lentelèje sudarytoje TAU universitetuose realizuojamų veiklų krypčių, suskirstytų i fakultetus schemoje. Tačiau pažymėtina, kad visų veiklų kontekste išsiskirianti dominantė - sveikata, sveika gyvensena, fizinis aktyvumas. Tai suponuoja prielaidą projektuoti su sveikata susijusių TAU fakultetų veiklas remiantis valstybės politikos kryptimis, susijusiomis su sveikatos profilaktika, sveikatos palaikymu ir sveika gyvensena. Pagrindu šiai nuostatai realizuoti galètų būti Nacionalinè mokslo programa „Sveikas senèjimas“, o jos priemonių sprendimai, nukreipti visuomenès sveikam senèjimui užtikrinti, panaudoti TAU veiklu turinio formavimui, metodiškam ir nuosekliam tikslinès auditorijos švietimui. Šiu veiklu realizavimui, A. Kalvaičio (2018) pastebejjimu, pasitelkiami ivairiu sričiu atstovai: biblioteku bei muziejų darbuotojai, savivaldybių ar nacionalinio lygio politikai, savanoriai, ivvairias praktikas atliekantys studentai, medikai, savivaldybès administracijos specialistai, verslininkai, knygų autoriai, policijos pareigūnai, dvasininkai, vyresniųjų klasių bendrojo ugdymo mokyklų mokiniai, pedagogai. Pastarųų įsitraukimas į vyresnio amžiaus asmenų švietimą rodo akademinès bendruomenès dalyvavimo svarbą realizuojant sveiko senejjimo idèją. Aukštujų mokyklų ir TAU bendradarbiavimas - palanki aplinkybė i Nacionalinę mokslo programą „Sveikas senëjimas“ issitraukusias aukštojo mokslo institucijas efektyviai pasiekti tikslinę auditoriją - vyresnio amžiaus asmenis - sukurtų ir realizuotų priemonių sveikam senėjimui užtikrinti informacijos sklaidai bei pritaikymui. Patiems TAU - tai kokybiškas, patikimas ir mokslinėmis inovacijomis grịstas resursas vyresnio amžiaus asmenų švietimui sveiko senejjimo srityje.

\section{Klaipėdos rajono TAU veikla sveiko senẻjimo kontekste}

Realizuojant tyrimo tikslą ir jo igyvendinimui išsikeltus uždavinius, išanalizuota mokslinė literatūra, aktualizuojanti senstančios visuomenès ir švietejjiškos veiklos sinergiją. Mokslinès įžvalgos papildytos sveiką senèjimą Lietuvos ir tarptautiniu mastu reglamentuojančių dokumentų apžvalga, paremta studijuotų dokumentų analize ir palyginimu. Teorinejje tyrimo dalyje akcentuotų ižvalgų projekcijai iliustruoti praktikoje pasirinktas Klaipėdos rajono TAU atvejis. Jo veiklų koordinavimas nuo $2011 \mathrm{~m}$. patikètas Klaipėdos rajono savivaldybės administracijai pavaldžiam Švietimo centrui remiantis rajono plètros strateginiu planu. Koks yra šios institucijos vykdomos veiklos potencialas realizuojant Nacionalinès mokslo programos „Sveikas senéjimas“ nuostatas, veiklos apimtys ir formos edukuojant tikslinę auditoriją - vyresnio amžiaus asmenis - atskleidžiama išanalizavus Klaipedos rajono švietimo centro pateiktus duomenis apie 2020 m.m. - 2021 m.m Klaipėdos rajono TAU veiklas: užsièmimų tematiką, formą ir apimtis.

I universiteto organizuojamas paskaitas, edukacijas ir užsièmimas renkasi vyresnio amžiaus asmenys, tačiau jų amžiaus kategorija griežtai neapibrèžiama. Per mokslo metus - apie 200 klausytojų. Mokslo metai ịprastai startuoja rudenį ir baigiasi pavasarį. Veiklos suskirstytos i 4 fakultetus: Asmeninès ūgties, Namų ūkio fakulteto, Užsienio kalbų fakulteto bei Fizinio aktyvumo ir sveikos gyvensenos fakulteto. Pastarojo fakulteto apibrèžtis suponuoja sąveiką su sveikata, tad ir 
užsièmimų turinyje bei formoje dominuoja sveikos gyvensenos ir fizinio aktyvumo aspektas. Tai - ne visada vien Fizinio aktyvumo ir sveikos gyvensenos fakulteto objektas. Sveikatos palaikymo temos ir užsièmimai dažni ir kitų fakultetų veiklų programoje. Ją ịvertinus išryškèja tematinès Klaipèdos rajono TAU veiklų dominantès, liudijančios Klaipėdos rajono vyresnio amžiaus asmenų švietimo ir užimtumo prioritetus (1 pav.).

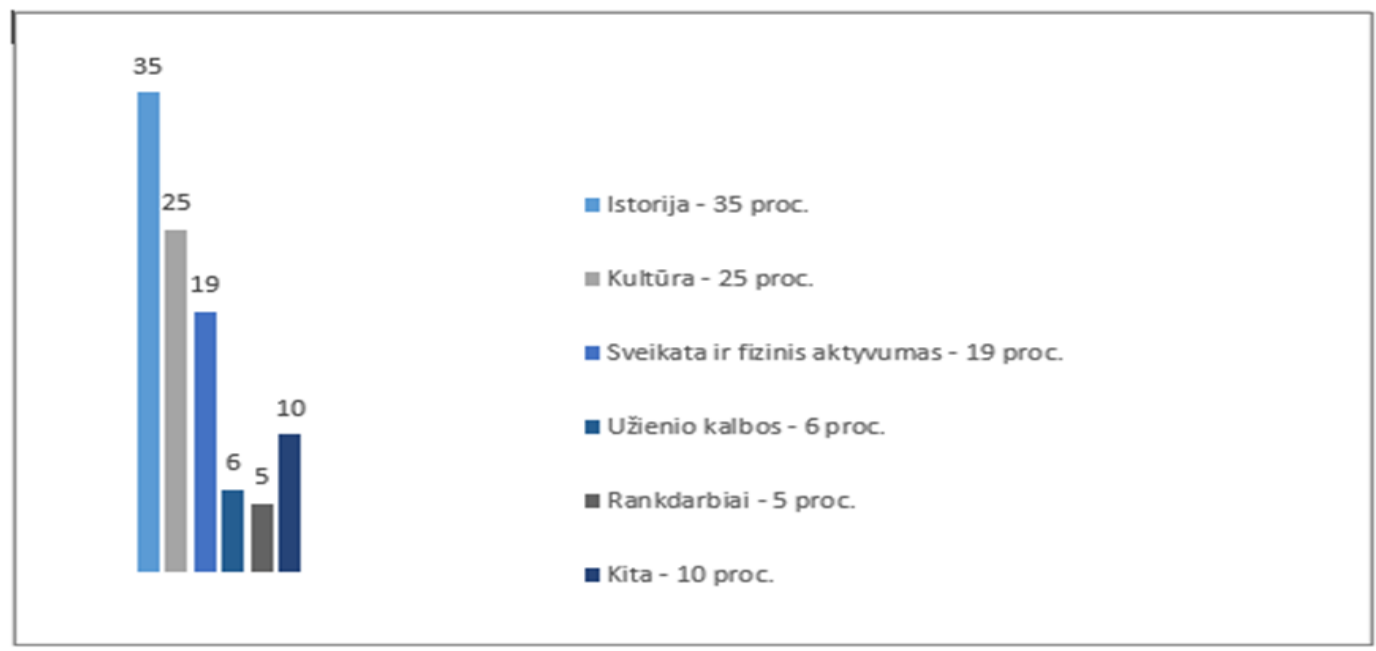

1 pav. Klaipėdos rajono TAU 2020-2021 m.m. užsièmimų teminis pasiskirstymas Šaltinis: sudaryta autorès pagal Klaipėdos rajono TAU 2020-2021 m.m. veiklų programą.

Klaipėdos rajono TAU 2020-2021 m.m. veiklų sąraše dominuoja kultūros (25 proc. paskaitų) ir istorijos temos (35 proc. paskaitų). Mažiausiai dėmesio skiriama užsienio kalbų tobulinimui (6 proc.) ir rankdarbiams (5 proc.). Su sveikata ir fiziniu aktyvumu susijusios temos sudaro 19 proc. paskaitu turinio. Kai kurios jų - šokiai, treniruotès - daro tiesioginę įtaką vyresnio amžiaus asmenų fiziniam aktyvumui. Tačiau dauguma jų - teorinio pobūdžio paskaitos apie įvairius sveikatos palaikymo ir profilaktikos veiksnius: meditaciją, emocinę sveikatą, atminties išsaugojimą, mitybos poveiki sveikatai, odos priežiūrą, Alzheimerio ligą.

Akcentuotina, kad vesti paskaitas ar užsièsimus 2020 - 2021 mokslo metais pakviesta nemažai aukštujų mokyklų atstovų. Daugelis jų - iš Klaipėdos valstybinès kolegijos, taip pat Klaipėdos universiteto, Vilniaus universiteto, Lietuvos sporto universiteto, Lietuvos sveikatos mokslų universiteto. Tai pagrindžia teorines ịžvalgas, kad bendradarbiavimas su aukštojo mokslo institucijomis - efektyvios TAU veiklos sąlyga, o tuo pačiu ir palanki prielaida žinių sklaidai bei populiarinimui apie mokslo inovacijas sveikam senėjimui užtikrinti - vienam iš Nacionalinès mokslo programos „Sveikas senèjimas“ prioritetų.

Pažymėtina, kad nemaža dalis aukštojo mokslo atstovų vestų paskaitų turi tiesioginių sąsajų su sveikatos švietimu, pvz.: „Mano puikioji atmintis: kaip pagerinti atmintį“ „Mitybos ịpročių keitimas ir antsvorio mažinimas“, „Nefarmakologinès sveikatos stiprinimo strategijos“, „Meditacijos metodai, gerinantys fizinę, psichologinę ir dvasinę sveikatą“, „Kaip išsaugoti smegenų jaunystę ir išvengti Alzhaimerio ligos. Tai iliustruoja, kaip TAU veikla atliepia Nacionalinès mokslo programos „Sveikas senejjimas“ nuostatą - išnaudoti mokslo potencialą sveiko ir kokybiško senejjimo užtikrinimui. Klaipėdos rajono vyresnio amžiaus asmenis telkiantis universitetas tam turi ypač palankią sąlygą - Klaipėdoje ịsikūrusių aukštųjų mokyklų kaimynystę ir galimybę i vyresnio amžiaus asmenų švietimą ịtraukti akademinès bendruomenès atstovus. Tai gerokai sudètingiau nuo auštojo mokslo institucijų atokiau esančių rajonų ar miestų TAU.

Klaipedos rajono TAU ir aukštojo mokslo institucijų sinergija - palanki prielaida pažvelgti i tokio bendradarbiavimo augimo potencialą pasitelkiant aukštojo mokslo intelektinius resursus. Žinių valdymo modelis; Psichologinių veiksnių ịtaka emocinei sveikatai; Moksliškai pagrịsti mitybos modeliai vyresnio amžiaus žmonėms; Moksliškai pagrịstų veiklų kompleksas fizinio aktyvumo skatinimui; Sveiką gyvenseną lemiantys socialiniai veiksniai; Viso gyvenimo mokymosi įtaka sveiko senejjimo užtikrinimui - rezultatas nuo 2019 m. vykdomo tarptautinio mokslinio tyrimo „Sveikas senejjimas“, ị kurị Klaipėdos valstybinè kolegija ịtraukta kaip partneris. Tyrimo pagrindu sukaupta 
mokslinė medžiaga, sukurti prototipai ir kita eksperimentinė veikla gali būti integruota į Klaipėdos rajono TAU veiklų planą ir tapti palankia prielaida ne tik Nacionalinės mokslo programos „Sveikas senèjimas, o ir kitų kokybiškam bei sveikam senejjimui kuriamų ir tokią veiklą reglamentuojančių rekomendacijų, gairių, strategijų bei programų realizavimui.

\section{Išvados ir rekomendacijos}

1. Klaipėdos rajono TAU savo veiklos specifika, tiksline auditorija ir veiklos organizavimo ypatumais yra efektyvus kanalas, kuriuo galima nuosekliai ir kryptingai vykdyti švietejjišką veiklą sveikam senejjimui užtikrinti. Vyresnio amžiaus asmenų įsitraukimas ị TAU veiklas sparčiai auga, kartu sudarydamas palankias aplinkybes švietėjiškai veiklai realizuoti.

2. Klaipedos rajono TAU veikloje akcentuotina tampri sąveika su aukštojo mokslo institucijomis. Tai pagrindžia teorines įžvalgas apie TAU universitetų veiklos orientavimąsi ị aukštojo mokslo institucijose kuriamą intelektini produktą. Jo panaudojimas atokiau nuo didmiesčių, o drauge ir aukštojo mokslo institucijų, ịsikūrusiuose TAU yra komplikuotas dèl ribotos galimybès pasikviesti pageidaujamus lektorius. Klaipėdos rajono TAU veiklos šios aplinkybès neriboja, o geografinè padètis - Klaipėdoje ịsikūrusių aukštujų mokyklų kaimynystė - palanki prielaida efektyviai veiklai.

3. Ne tik vyresnio amžiaus asmenis telkiantys TAU, o ir auštosios mokyklos suinteresuotos sveikam senèjimui būtina švietejiška veikla. Rezultatas - mokslo taikomosios ir eksperimentinès veiklos produktai. Žinios sklaida apie jų panaudojimą ir pritaikymą užtikrinant sveiką senatvę gali būti integruota ị TAU veiklų planą ir tapti palankia prielaida ne tik Nacionalinès mokslo programos „Sveikas senejjimas, o ir kitų kokybiškam bei sveikam senejjimui kuriamų ir tokią veiklą reglamentuojančių rekomendacijų, gairių, strategijų bei programų realizavimui.

\section{Literatūra}

1. Bagdonas, A., Kairys, A., Liliauskaitè, A., Pakalniškytè, V. (2013). Lietuvos gyventojų psichologinè gerovė ir jos veiksniai. Monografija. Vilnius: VU leidykla.

2. Europos Sajungos statistikos tarnyba. (žiūrèta 2021-09-16). Prieiga per internetą: https://ec.europa.eu/eurostat/documents/3433488/5564440/KS-SF-10-001-EN.PDF.pdf/d5b8bf546979-4834-998a-f7d1a61aa82d?t=1414692757000

3. Final report of the expert group on quality of life indicators 2017 edition (žiūrèta 2021-09-16). Prieiga per internetą: https://ec.europa.eu/eurostat/documents/7870049/7960327/KS-FT-17-004EN-N.pdf/f29171db-e1a9-4af6-9e96-730e7e11e02f

4. Gustaitienè, L., Barauskaitè, M. (2018). Sėkmingas senėjimas: daugiadimensis požiūris. Socialinis darbas. Patirtis ir metodai. 21 (1). VDU. (žiūrèta 2021-09-16). Prieiga per internetą: https://www.vdu.lt/cris/bitstream/20.500.12259/59943/1/ISSN2029-820_2018_N_21_1.PG_8197.pdf

5. Kalvaitis, A. (2018). Trečiojo amžiaus universitetai Lietuvoje. $2018 \mathrm{~m}$. situacija. Vilnius. Kvalifikacijos ir procesinio mokymo plètotès centras. (žiūrèta 2021-09-16). Prieiga per internetą: https://www.nsa.smm.lt/wp-content/uploads/2020/07/Treciojo-amziaus-universitetai-Lietuvoje..pdf

6. Kalvaitis, A., Baranauskienè, J., Mačènaitè, A. (2014). Trečiojo amžiaus universitetai Lietuvoje: situacijos analizė ir plètros gairès. Vilnius. Ugdymo plètotès centras. (žiūrèta 2021-09-16). Prieiga per internetą: https://www.kpmpc.lt/kpmpc/wp-content/uploads/2014/01/Tre\%C4\%8Diojoam\%C5\%BEiaus-universitetai-Lietuvoje-situacijos-analiz\%C4\%97-ir-pl\%C4\%97trosgair\%C4\%97s.pdf

7. Larkin, M. 2013. Health and Well-Being across the Life Course. Los Angeles et al.: Sage. Prieiga per internetą: https://us.sagepub.com/en-us/nam/health-and-well-being-across-the-lifecourse/book235932

8. Lietuvos Respublikos neformaliojo suaugusiųjų švietimo ir tęstinio mokymosi įstatymas. Prieiga per internetą: https://e-seimas.lrs.lt/portal/legalAct/lt/TAD/4fbc2512bac711ea9a12d0dada3ca61b 
9. Lietuvos Respublikos sveikatos apsaugos ministro įsakymas dèl sveiko senėjimo užtikrinimo Lietuvoje 2014-2023 m. veiksmų plano patvirtinimo. Prieiga per internetą: https://eseimas.lrs.lt/portal/legalAct/lt/TAD/4ae918500ebf11e48595a3375cdcc8a3/asr

10. Lietuvos Respublikos švietimo įstatymas. Prieiga per internetą: http://e-seimas.lrs.lt/ portal/legalActEditions/lt/TAD/TAIS.1480

11. Lietuvos Respublikos švietimo ir mokslo ministro įsakymas dèl nacionalinès mokslo programos „Sveikas senejjimas patvirtinimo. Prieiga per internetą: https://www.e-tar.lt/portal/lt/ legalAct/8b5db9b0ad2811e4b1d79f4bef60993c/asr

12. Martin, D. J., Gollen, L. (2014). Revisiting Gerontology's Scrapbook: From Metchnikoff to the Spectrum Model of Aging. The Gerontologist, 54 (1). Prieiga per internetą: https://pubmed.ncbi.nlm.nih.gov/23893558/

13. Merriam, S. B., Bierema, L. L. (2014). Adult learning: Linking theory and practice. San Francisco, CA: Jossey-Bass. Prieiga per internetą: https://unbound.upcea.edu/leadership-strategy/continuingeducation/adult-learning-linking-theory-and-practice-by-sharan-b-merriam-laura-l-bierema-josseybass-san-francisco-2014

14. Nacionalinè trečiojo amžiaus universitetų asociacija (žiūrèta 2021-09-16). Prieiga per internetą: http://www.tauasociacija.lt/home

15. Staškutè, I. (2014). Su sveikata susijusios gyvenimo kokybès samprata, stebèsenos ir vertinimo metodai bei reikšmé sveikatos politikoje. Sveikatos politika ir valdymas. Prieiga per internetą: https://repository.mruni.eu/bitstream/handle/007/12546/1632-4787-1-PB.pdf?sequence=1\&isAllowed=y

16. Stephen, K., Calasanty, T. (2015). Critical Perspectives on Successful Aging: Does It "Appeal More Than It Illuminates"? The Gerontologist, Vol. 55, No. 1. Oxford. Prieiga per internetą: https://academic.oup.com/gerontologist/article/55/1/26/570332

17. Wister, A. V. Malloy-Weir, L.J., Rootman, I. (2010). Lifelong Educational Practices and Resources in Enabling Health Literacy Among Older Adults. Journal of Aging and Health. Vol. 22, No 6. Prieiga per internetą: file:///C:/Users/Vartotojas/Downloads/Wisteretal2010_lifelongeducational.pdf

\section{THE UNIVERSITY OF THE THIRD AGE IN THE CONTEXT OF NATIONAL SCIENCE PROGRAM HEALTHY AGING: THE CASE OF KLAIPEDA DISTRICT}

\section{Laura Sèlenienė}

\section{Summary}

The thesis presents challenges facing the aging society. One such challenge is ensuring healthy and dignified old age. Its importance is demonstrated by the abundance of recommendations, programs, guidelines, and strategies related to the quality of life of the elderly. The National Science Program Healthy Aging is one of the documents defining the problems of the aging society. Its content emphasizes the contribution of science in solving these problems. In this context, the emphasis is put not only on scientific decisions but also on their dissemination to the target audience - the elderly. This promotes the importance of inter-institutional interaction. The thesis singles out the interaction between the higher education institutions and organizations intended for the elderly as one of the preconditions for the implementing of the idea of healthy aging. It presupposes the need to assess the integration of scientific solutions into the education of the elderly and the potential of such organizations of the context of healthy aging.

The object of the research is the University of the Third Age (U3A) of Klaipeda District.

The research aims to evaluate the potential of the U3A of Klaipeda District in implementing the provisions of the National Science Program Healthy Aging.

Objectives:

1. To identify the scope and forms of the U3A of Klaipeda District.

2. To evaluate how the U3A of Klaipeda District corresponds with the guidelines of the National Science Program Healthy Aging.

3. To prepare recommendations for the efficiency of the U3A of Klaipeda District.

Research methods: review of scientific literature, document study, data analysis.

The research has demonstrated that the specifics of the U3A of Klaipeda District, its target audience, and the organizational practices are effective channels through which educational activities can be carried out consistently and purposefully to ensure healthy aging. The interest of the elderly in the U3A is growing rapidly while creating favourable conditions for the implementation of educational activities. 
The U3A of Klaipeda District promotes close cooperation with higher education institutions. This substantiates theoretical insights about the U3A focusing on the intellectual product developed in the higher education institutions. Its application farther from larger cities, and, consequently, from higher education institutions, is complicated due to limited abilities to invite prominent lectors. These circumstances do not limit the activities of the U3A of Klaipeda District, and the higher education institutions located in Klaipeda is a favourable precondition for efficient activities.

Educational activities are crucial not only for the U3A but also for the higher education institutions concerned about healthy aging. The result is the product of applied science and experimentation. Dissemination of knowledge about their use and application in ensuring healthy aging can be integrated into the U3A action plan and become a favourable precondition not only for the implementation of the National Science Program Healthy Aging but also other recommendations, guidelines, strategies, and programs aimed at dignified and healthy aging.

Keywords: healthy aging, University of the Third Age, the elderly. 